\title{
Unseiin, a Kampo medicine, Reduces the Severity and Manifestations of Skin Toxicities Induced by Cetuximab: A Case Report
}

\author{
Kenkichiro Taira,* Kazunori Fujiwara,* Takahiro Fukuhara,* Tsuyoshi Morisaki,* Satoshi Koyama," \\ Ryohei Donishi* and Hiromi Takeuchi* \\ *Division of Otolaryngology, Head and Neck Surgery, Department of Sensory and Motor Organs, School of Medicine, Faculty of \\ Medicine, Tottori University, Yonago 683-8504, Japan
}

\begin{abstract}
Cetuximab is an effective drug used to treat patients with recurrent or metastatic head and neck squamous cell carcinoma. Skin toxicities such as paronychia and skin exsiccation are common adverse events caused by cetuximab. Skin toxicities may cause significant physical and psychosocial discomfort. The goal of managing skin toxicities is to minimize the detrimental effects on quality of life and continue the treatment. In one patient, skin toxicities became severe, up to grade 2, during treatment. The pain induced by paronychia and skin exsiccation made daily life difficult. Ten days after starting Unseiin, symptoms and finger findings resolved significantly. The patient could resume daily activities. No adverse effects induced by Unseiin were observed during treatment. Unseiin was effective on paronychia and skin exsiccation in this case and may contribute to successful treatment of skin toxicities induced by cetuximab.
\end{abstract}

Key words cetuximab; epidermal growth factor receptor inhibitor; Kampo medicine; paronychia skin toxicities

Cetuximab (Cmab) is an effective drug for patients with recurrent or metastatic head and neck squamous cell carcinoma (HNSCC). ${ }^{1,2}$ Skin toxicities such as paronychia and skin exsiccation are adverse events that are more commonly associated with $\mathrm{Cmab}$ than anti-cancer agents such as platinum-based drugs, taxanes, and fluoropyrimidine-based formulations which have been used in patients with HNSCC. ${ }^{3-5}$ Skin toxicities are seen in approximately $80 \%$ of patients treated with $\mathrm{Cmab} .{ }^{6-8}$ However, paronychia and skin fissures often cause severe, intolerable pain in the fingers and toes, although

Corresponding Author: Kenkichiro Taira, MD

kenkichiro.t@tottori-u.ac.jp

Received 2020 October 1

Accepted 2020 October 28

Online published 2020 November 24

Abbreviations: AD, atopic dermatitis; ADL, activities of daily livings; Cmab, cetuximab; EGFR, epidermal growth factor receptor inhibitor; HNSCC, head and neck squamous cell carcinoma; QOL, quality of life they are rarely life-threatening. ${ }^{9-11}$ These adverse events make it impossible to perform daily life activities such as grasping something and walking. When these adverse events are severe, quality of life (QOL) is impaired because of pain and discomfort. ${ }^{12}$ This leads to loss of motivation and treatment compliance. Unless properly managed, they can result in dose reduction and discontinuation of treatment, which occurs in approximately $15-25 \%$ of patients. ${ }^{13,14}$ Cmab should be continued if it has a confirmed therapeutic effect. It is reported that the management such as topical corticosteroids or oral tetracyclines have been used for the treatment of skin toxicities. ${ }^{15}$ However, definitive management for skin toxicities induced by $\mathrm{Cmab}$ has not been established yet. Therefore, effective management of these skin toxicities is required to maximize treatment efficacy and maintain QOL.

\section{PATIENT REPORT}

The patient was a 64-year-old man. He had previously received treatment for hypopharyngeal HNSCC (stage cT1N2bM0) consisting of cisplatin-based concomitant chemoradiotherapy and bilateral neck dissection. Lymph node metastasis was found in the left neck 37 months after these treatments. Intravenous $\mathrm{Cmab}$ and carboplatin once weekly were planned as maintenance chemotherapy. The patient's past medical history included heart failure and coronary atherosclerosis.

Initial carboplatin dosage based on the Calvert method was only approximately $300 \mathrm{mg}$. The initial dosage of Cmab was $400 \mathrm{mg} / \mathrm{m}^{2}$. The Cmab dosage after initial administration was $250 \mathrm{mg} / \mathrm{m}^{2}$ once a week. His other medications included minocycline $100 \mathrm{mg} /$ day and a moisturizer to reduce the severity of skin toxicity at the same time as the start of initial dosage of Cmab (day 1). A grade 1 acneiform rash was found 5 days after the initial Cmab dose. Cmab-induced skin toxicity was evaluated and graded using the Common Toxicity Criteria for Adverse Events version 4.0 by the same medical oncologist throughout treatment. Table 1 shows that skin toxicity included rash acneiform, skin pain, and subcutaneous tissue disorders, that is, others, specifically paronychia and skin fissures. 
Table 1. Grading skin toxicities associated with EGFR inhibitors according to NCI-CTC AE version 4.0

\begin{tabular}{|c|c|c|c|c|c|}
\hline Adverse event & Grade 1 & Grade 2 & Grade 3 & Grade 4 & Grade 5 \\
\hline Rash acneiform & $\begin{array}{l}\text { Papules and/or } \\
\text { pustules covering } \\
<10 \% \text { BSA which } \\
\text { may or may not } \\
\text { be associated with } \\
\text { symptoms of pruri- } \\
\text { tus or tenderness }\end{array}$ & $\begin{array}{l}\text { Papules and/or } \\
\text { pustules covering } \\
10-30 \% \text { BSA, } \\
\text { which may or may } \\
\text { not be associated } \\
\text { with symptoms of } \\
\text { pruritus or tender- } \\
\text { ness; associated } \\
\text { with psychosocial } \\
\text { impact; limiting } \\
\text { instrumental ADL }\end{array}$ & $\begin{array}{l}\text { Papules and/or } \\
\text { pustules covering } \\
>30 \% \text { BSA, which } \\
\text { may or may not } \\
\text { be associated with } \\
\text { symptoms of pru- } \\
\text { ritus or tenderness; } \\
\text { limiting self care } \\
\text { ADL; associated } \\
\text { with local super- } \\
\text { infection with oral } \\
\text { antibiotics indicated }\end{array}$ & $\begin{array}{l}\text { Papules and/or } \\
\text { pustules covering } \\
\text { any \% BSA, which } \\
\text { may or may not } \\
\text { be associated with } \\
\text { symptoms of pru- } \\
\text { ritus or tenderness } \\
\text { and are associ- } \\
\text { ated with extensive } \\
\text { superinfection with } \\
\text { IV antibiotics indi- } \\
\text { cated; lifethreaten- } \\
\text { ing consequences }\end{array}$ & death \\
\hline Skin pain & Mild pain & $\begin{array}{l}\text { Moderate pain; lim- } \\
\text { iting instrumental } \\
\text { ADLs }\end{array}$ & $\begin{array}{l}\text { Severe pain; limit- } \\
\text { ing self-care ADLs }\end{array}$ & - & - \\
\hline $\begin{array}{l}\text { Skin and subcutane- } \\
\text { ous tissue disorders, } \\
\text { and others specifi- } \\
\text { cally paronychia and } \\
\text { skin fissures }\end{array}$ & $\begin{array}{l}\text { Asymptomatic or } \\
\text { mild symptoms; } \\
\text { clinical or diag- } \\
\text { nostic observations } \\
\text { only; intervention } \\
\text { not indicated }\end{array}$ & $\begin{array}{l}\text { Moderate; minimal, } \\
\text { local or noninva- } \\
\text { sive intervention } \\
\text { indicated; limiting } \\
\text { age-appropriate in- } \\
\text { strumental ADLs }\end{array}$ & $\begin{array}{l}\text { Severe or medi- } \\
\text { cally significant but } \\
\text { not immediately } \\
\text { life-threatening; } \\
\text { hospitalization or } \\
\text { prolongation of } \\
\text { existing hospital- } \\
\text { ization indicated; } \\
\text { disabling; limiting } \\
\text { self care ADLs }\end{array}$ & $\begin{array}{l}\text { Life-threatening } \\
\text { consequences; } \\
\text { urgent intervention } \\
\text { indicated }\end{array}$ & Death \\
\hline
\end{tabular}

BSA, body surface area.

A steroid was started for topical use to manage skin toxicity since acneiform rash was found (day 5). Paronychia and skin fissures caused by skin exsiccation on several fingers were found one day after the second Cmab dose (day 9). These skin toxicities became severe, up to grade 2, before the third Cmab dose (Fig. 1). Subsequently, finger pain progressed to grade 3, which made it difficult to hold chopsticks and pencils as part of daily life activities. In addition to the initial management for skin toxicities, a Japanese traditional medicine (Kampo) called Unseiin was prescribed at $2.5 \mathrm{~g}$ three times daily when the third Cmab dose was started (day 22). At 10 days after starting Unseiin, symptoms and findings in the fingers resolved significantly (Fig. 2). The patient could resume daily activities. Cmab was continued with no exacerbation of these skin toxicities for the third to fifth doses. Two months later, CT showed progression of lymph node metastasis and chemotherapy was discontinued. No adverse effects associated with Unseiin were observed during treatment. The clinical course is shown in Fig. 3.

\section{DISCUSSION}

It has been reported that more than $80 \%$ of patients who receive $\mathrm{Cmab}$ experience skin toxicity; approximately $25 \%$ of patients require treatment interruption or discontinuation. ${ }^{6-8,13,14}$ The skin toxicities induced by Cmab usually lessen within 1 month after discontinuation. ${ }^{15,} 16$ However, occurrence of more severe Cmabinduced skin toxicity is correlated with better treatment response and longer survival in several studies across multiple malignancies. ${ }^{12,17,18}$ Cmab therapy should be continued if it has a therapeutic effect. Therefore, it is important to manage skin toxicities such as paronychia and skin fissures because treatment interruption and discontinuation due to the severity of skin toxicity should be avoided in order to achieve maximum benefit. In our case, the paronychia and skin fissures had to be improved because of significant pain, functional limitation, and impairment in daily living. Topical corticosteroid and anti-inflammatory dose tetracycline to decrease periungual inflammation and antimicrobial to prevent superinfection are recommended for paronychia. ${ }^{19-21}$ Skin fissures and cracks often occur in the fingertips due to significant xerosis. ${ }^{15}$ Liquid glues like cyanoacrylate preparations can be used to seal the cracks and 


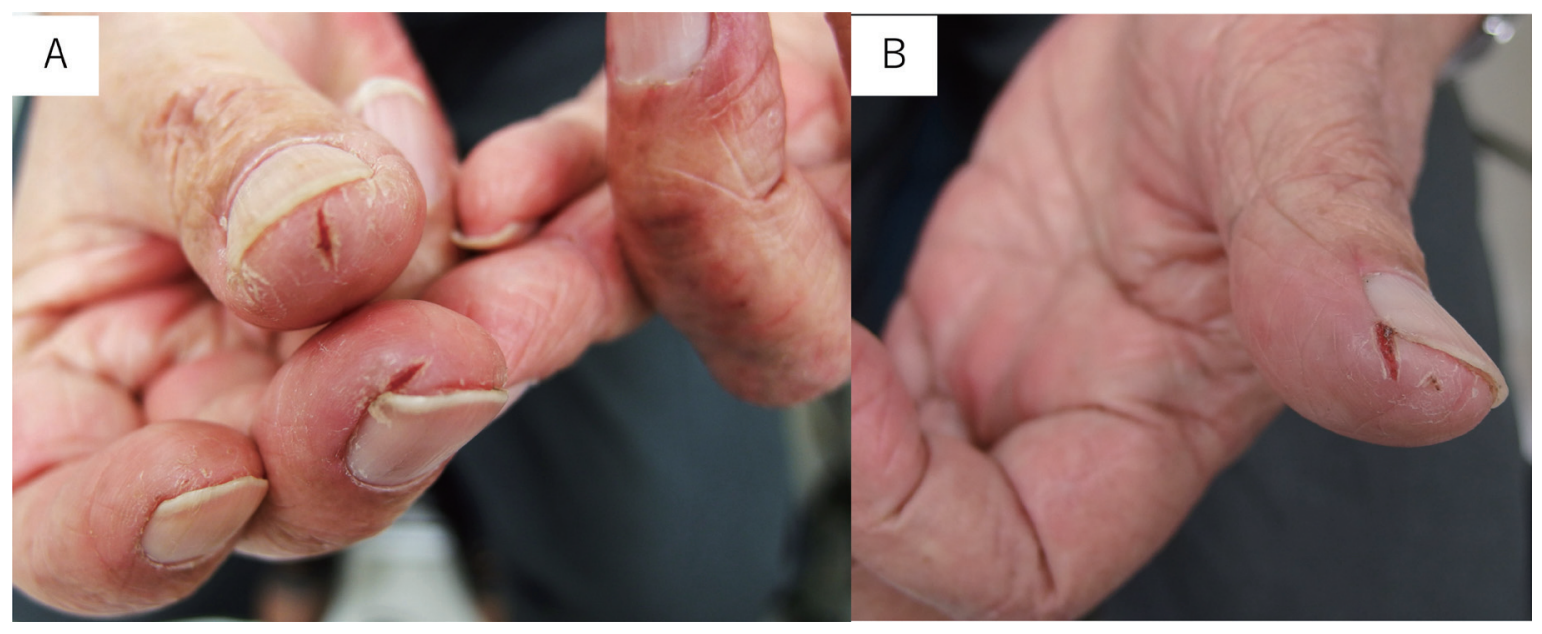

Fig. 1. Before treatment with Unseiin. Paronychia and skin fissures caused by skin exsiccation. A: Right fingers. B: Left fingers.

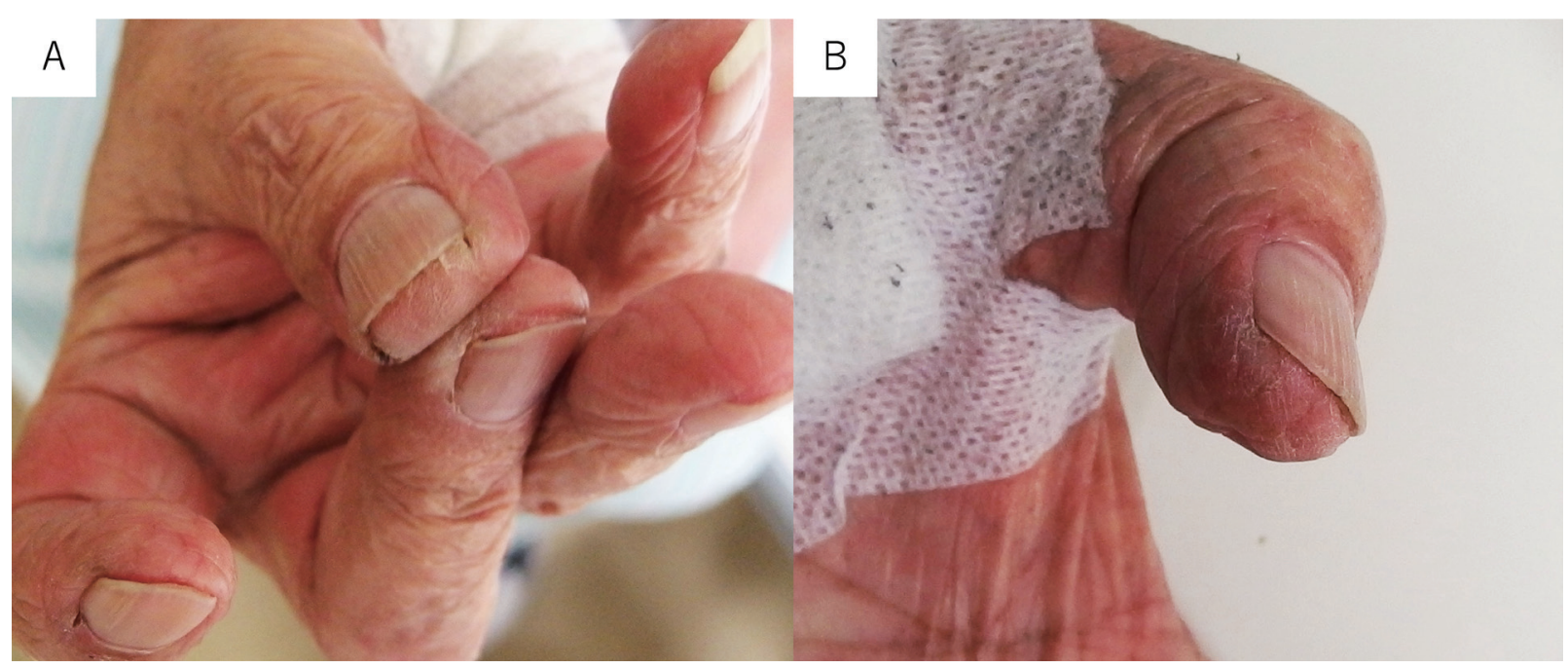

Fig. 2. Ten days after treatment with Unseiin. Significant improvement of skin exsiccation. A: Right fingers. B: Left fingers.

keep them from worsening. ${ }^{22-25}$ Hydrocortisone with moisturizer and prophylactic minocycline $100 \mathrm{mg}$ daily is possible as an effective agent in improving acneiform rash. ${ }^{15}$ However, there have been no clear effectiveness patterns for these skin toxicities. ${ }^{12,15,26}$ In our case, these treatments were less effective. Thus, more effective agents had to be taken into consideration to reduce the discomfort of skin toxicities.

This is the first report showing that Unseiin is effective for skin toxicities induced by Cmab. In our patient, skin toxicity was progressing due to the continuation of Cmab. Unseiin was effective for paronychia and skin fissures; these symptoms of skin toxicities lessened without treatment interruption. Unseiin is used to treat pruritic cutaneous diseases such as eczema and skin eruptions. ${ }^{27}$ Four herbal compounds including
Unseiin are effective for inflammatory skin disease such as atopic dermatitis (AD) that involve a skin barrier defect. ${ }^{28}$ These four herbal compounds are Coptis Chinensis, Phellodendri Cortex, Scutellariae Radix, Gardeniae Fructus which can correct the Th1/Th2 cells balance skewed to Th2 cells. $^{28}$

Cmab inhibits the expression of epidermal growth factor receptor (EGFR) in the skin. ${ }^{9}$ Inhibition of EGFR-mediated signaling pathways reduces keratinocyte proliferation by inducing growth arrest and apoptosis, decreasing cell migration, and increasing cell attachment and differentiation. ${ }^{9,} 29$ These effects lead to defective barrier function of the skin. Chronic impairment of the skin barrier in conditions like $\mathrm{AD}$ leads to direct exposure to antigens and upregulation of Th2 activity, thereby increasing cytokine production. ${ }^{30}$ 


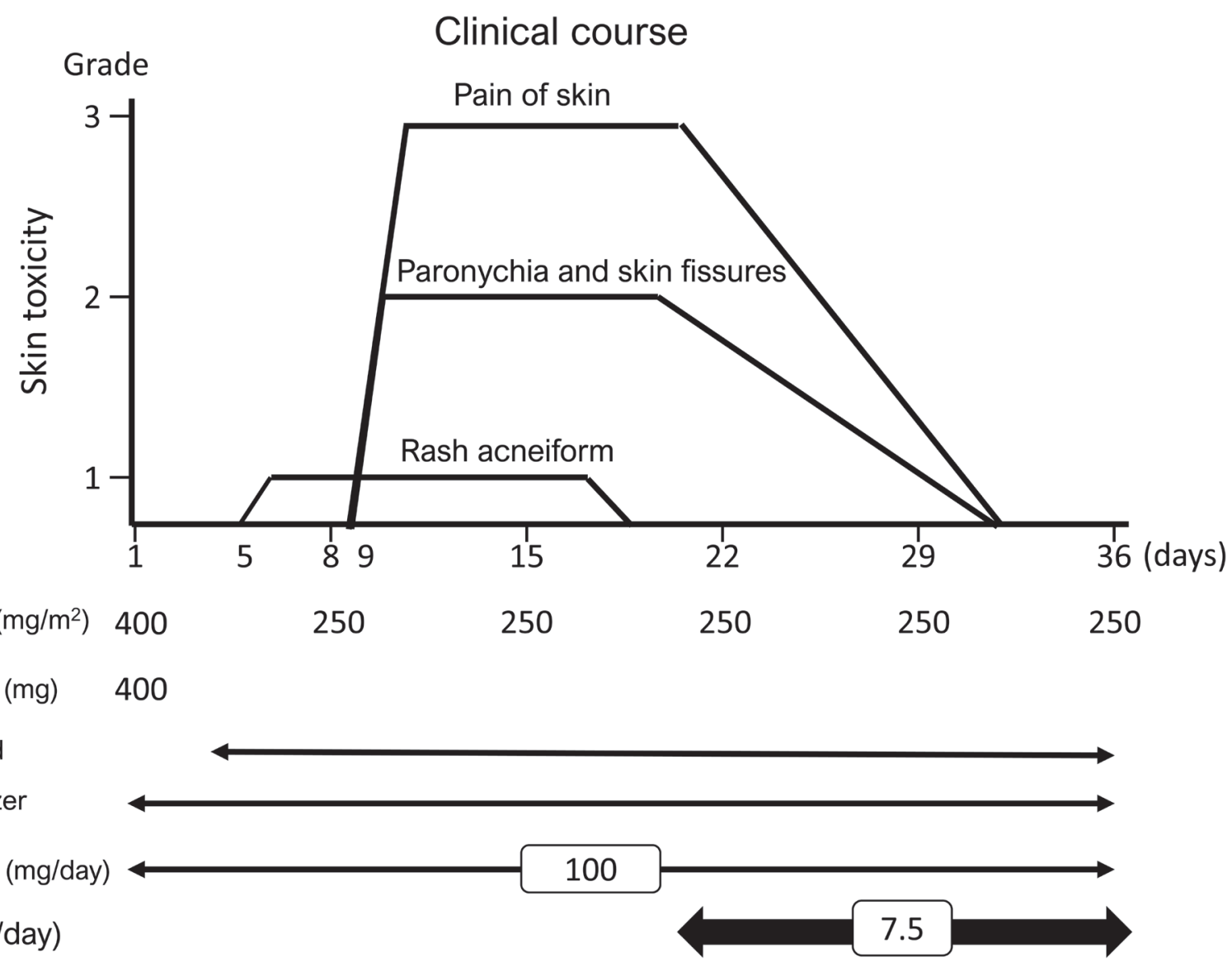

Fig. 3. Clinical course. Cmab could be continued without interruption.

This causes further progression of the skin disorder. Unseiin including four herbal compounds suppresses hypersensitivity reactions associated with Th2 cells. It seems to downregulate Th2 activity and prevent severe dermatitis.

Skin barrier defects cause secondary bacterial infections, which can worsen the symptoms of skin inflammation. Unseiin is composed of eight herbal compounds: Coptis Chinensis, Phellodendri Cortex, Scutellariae Radix, Gardeniae Fructus, Angelicae Radix, Cnidii Rhizoma, Paeoniae Radix, and Rehmanniae Radix. Several herbal substances are associated with mechanisms that reduce the severity of inflammation and pain. It has been reported that Coptis Chinensis and Angelicae Radix have antibacterial activities $^{31}$ and Coptis Chinensis and Phellodendri Cortex have anti-inflammatory activity and suppress the production of prostaglandin E2, which induces pain. ${ }^{32-37}$ We speculate that these pharmacological actions are effective for reducing symptoms and the severity of skin toxicities caused by Cmab. In this case, chemotherapy was completed because of reduced skin toxicity after
Unseiin was started. Therefore, Unseiin may contribute to successful treatment of skin toxicities induced by Cmab. One limitation is shown in a case report of a patient with head and neck cancer where there is a lack of evidence-based clinical guidelines for management. More data are needed to confirm the positive relationship between skin toxicity and clinical response of Unseiin.

In conclusion, Unseiin was effective for paronychia and skin exsiccation. Further studies are also required to fully understand the biological activity of Unseiin against skin toxicities.

Consent for publication: Informed consent was obtained from the patient regarding the publication of the details of this case and associated images.

The authors declare no conflict of interest. 


\section{REFERENCES}

1 Ongkeko WM, Altuna X, Weisman RA, Wang-Rodriguez J. Expression of protein tyrosine kinases in head and neck squamous cell carcinomas. Am J Clin Pathol. 2005;124:71-6. DOI: 10.1309/BTLN5WTMJ3PCNRRC, PMID: 15923166

2 Temam S, Kawaguchi H, El-Naggar AK, Jelinek J, Tang H, Liu DD, et al. Epidermal growth factor receptor copy number alterations correlate with poor clinical outcome in patients with head and neck squamous cancer. J Clin Oncol. 2007;25:2164-70. DOI: 10.1200/JCO.2006.06.6605, PMID: 17538160

3 Jonker DJ, O'Callaghan CJ, Karapetis CS, Zalcberg JR, Tu $\mathrm{D}, \mathrm{Au} \mathrm{HJ}$, et al. Cetuximab for the treatment of colorectal cancer. N Engl J Med. 2007;357:2040-8. DOI: 10.1056/ NEJMoa071834, PMID: 18003960

4 Wacker B, Nagrani T, Weinberg J, Witt K, Clark G, Cagnoni PJ. Correlation between development of rash and efficacy in patients treated with the epidermal growth factor receptor tyrosine kinase inhibitor erlotinib in two large phase III studies. Clin Cancer Res. 2007;13:3913-21. DOI: 10.1158/1078-0432. CCR-06-2610, PMID: 17606725

5 Giovannini M, Gregorc V, Belli C, Roca E, Lazzari C, Viganò MG, et al. Clinical Significance of Skin Toxicity due to EGFR-Targeted Therapies. J Oncol. 2009;2009:1-8. DOI: 10.1155/2009/849051, PMID: 19584908

6 Bonomo P, Loi M, Desideri I, Olmetto E, Delli Paoli C, Terziani $\mathrm{F}$, et al. Incidence of skin toxicity in squamous cell carcinoma of the head and neck treated with radiotherapy and cetuximab: A systematic review. Crit Rev Oncol Hematol. 2017;120:98-110. DOI: 10.1016/j.critrevonc.2017.10.011, PMID: 29198343

7 Petrelli F, Borgonovo K, Barni S. The predictive role of skin rash with cetuximab and panitumumab in colorectal cancer patients: a systematic review and meta-analysis of published trials. Target Oncol. 2013;8:173-81. DOI: 10.1007/s11523-0130257-x, PMID: 23321777

8 Su X, Lacouture ME, Jia Y, Wu S. Risk of high-grade skin rash in cancer patients treated with cetuximab--an antibody against epidermal growth factor receptor: systemic review and meta-analysis. Oncology. 2009;77:124-33. DOI: 10.1159/000229752, PMID: 19622903

9 Lacouture ME. Mechanisms of cutaneous toxicities to EGFR inhibitors. Nat Rev Cancer. 2006;6:803-12. DOI: 10.1038/ nrc1970, PMID: 16990857

10 Solomon BM, Jatoi A. Rash from EGFR inhibitors: opportunities and challenges for palliation. Curr Oncol Rep. 2008;10:304-8. DOI: 10.1007/s11912-008-0048-1, PMID: 18778556

11 Wagner LI, Lacouture ME. Dermatologic toxicities associated with EGFR inhibitors: the clinical psychologist's perspective. Impact on health-related quality of life and implications for clinical management of psychological sequelae. Oncology (Williston Park). 2007;21(suppl 5):34-6. PMID: 18154217

12 Rothschild SI, Betticher D, Zenhäusern R, Anchisi S, von Moos R, Pless M, et al. Prospective, observational practice survey of applied skin care and management of cetuximab-related skin reactions: PROSKIN study. Cancer Chemother Pharmacol. 2019;84:881-9. DOI: 10.1007/s00280019-03927-x, PMID: 31444619
13 Van Cutsem E, Köhne CH, Hitre E, Zaluski J, Chang Chien $\mathrm{CR}$, Makhson A, et al. Cetuximab and chemotherapy as initial treatment for metastatic colorectal cancer. N Engl J Med. 2009;360:1408-17. DOI: 10.1056/NEJMoa0805019, PMID: 19339720

14 Vermorken JB, Mesia R, Rivera F, Remenar E, Kawecki A, Rottey S, et al. Platinum-based chemotherapy plus cetuximab in head and neck cancer. N Engl J Med. 2008;359:1116-27. DOI: 10.1056/NEJMoa0802656, PMID: 18784101

15 Lacouture ME, Anadkat MJ, Bensadoun RJ, Bryce J, Chan A, Epstein JB, et al.; MASCC Skin Toxicity Study Group. Clinical practice guidelines for the prevention and treatment of EGFR inhibitor-associated dermatologic toxicities. Support Care Cancer. 2011;19:1079-95. DOI: 10.1007/s00520-0111197-6, PMID: 21630130

16 Li T, Perez-Soler R. Skin toxicities associated with epidermal growth factor receptor inhibitors. Target Oncol. 2009;4:10719. DOI: 10.1007/s11523-009-0114-0, PMID: 19452131

17 Uozumi S, Enokida T, Suzuki S, Nishizawa A, Kamata H, Okano T, et al. Predictive Value of Cetuximab-Induced Skin Toxicity in Recurrent or Metastatic Squamous Cell Carcinoma of the Head and NECK. Front Oncol. 2018;8:616. DOI: 10.3389/fonc.2018.00616, PMID: 30619755

18 Peréz-Soler R, Saltz L. Cutaneous adverse effects with HER1/ EGFR-targeted agents: is there a silver lining? J Clin Oncol. 2005;23:5235-46. DOI: 10.1200/JCO.2005.00.6916, PMID: 16051966

19 Tosti A, Piraccini BM, Ghetti E, Colombo MD. Topical steroids versus systemic antifungals in the treatment of chronic paronychia: an open, randomized double-blind and double dummy study. J Am Acad Dermatol. 2002;47:73-6. DOI: 10.1067/mjd.2002.122191, PMID: 12077585

20 Wollina U. Acute paronychia: comparative treatment with topical antibiotic alone or in combination with corticosteroid. J Eur Acad Dermatol Venereol. 2001;15:82-4. DOI: 10.1046/ j.1468-3083.2001.00177-6.x, PMID: 11451337

21 Rigopoulos D, Gregoriou S, Belyayeva E, Larios G, Kontochristopoulos G, Katsambas A. Efficacy and safety of tacrolimus ointment $0 \cdot 1 \%$ vs. betamethasone 17 -valerate $0 \cdot 1 \%$ in the treatment of chronic paronychia: an unblinded randomized study. Br J Dermatol. 2009;160:858-60. DOI: 10.1111/ j.1365-2133.2008.08988.x, PMID: 19120329

22 Burtness B, Anadkat M, Basti S, Hughes M, Lacouture ME, McClure JS, et al. NCCN Task Force Report: management of dermatologic and other toxicities associated with EGFR inhibition in patients with cancer. J Natl Compr Canc Netw. 2009;7(Suppl_1):S-5-21. DOI: 10.6004/jnccn.2009.0074

23 Aygenc E, Celikkanat S, Kaymakci M, Aksaray F, Ozdem C. Prophylactic effect of pentoxifylline on radiotherapy complications: a clinical study. Otolaryngol Head Neck Surg. 2004;130:351-6. DOI: 10.1016/j.otohns.2003.08.015, PMID: 15054378

$24 \mathrm{Hu}$ JC, Sadeghi P, Pinter-Brown LC, Yashar S, Chiu MW. Cutaneous side effects of epidermal growth factor receptor inhibitors: clinical presentation, pathogenesis, and management. J Am Acad Dermatol. 2007;56:317-26. DOI: 10.1016/ j.jaad.2006.09.005, PMID: 17141360

25 Shah NT, Kris MG, Pao W, Tyson LB, Pizzo BM, Heinemann $\mathrm{MH}$, et al. Practical management of patients with nonsmall-cell lung cancer treated with gefitinib. J Clin Oncol. 2005;23:165-74. DOI: 10.1200/JCO.2005.04.057, PMID: 15557594 
26 Watanabe S, Nakamura M, Takahashi H, Hara M, Ijichi K, Kawakita D, et al. Dermopathy associated with cetuximab and panitumumab: investigation of the usefulness of moisturizers in its management. Clin Cosmet Investig Dermatol. 2017;10:353-61. DOI: 10.2147/CCID.S140796, PMID: 28932126

27 Andoh T, Al-Akeel A, Tsujii K, Nojima H, Kuraishi Y. Repeated treatment with the traditional medicine Unsei-in inhibits substance P-induced itch-associated responses through downregulation of the expression of nitric oxide synthase 1 in mice. J Pharmacol Sci. 2004;94:207-10. DOI: 10.1254/ jphs.94.207, PMID: 14978361

28 Gao XK, Fuseda K, Shibata T, Tanaka H, Inagaki N, Nagai H. Kampo Medicines for Mite Antigen-Induced Allergic Dermatitis in NC/Nga Mice. Evid Based Complement Alternat Med. 2005;2:191-9. DOI: 10.1093/ecam/neh077, PMID: 15937560

29 Kari C, Chan TO, Rocha de Quadros M, Rodeck U. Targeting the epidermal growth factor receptor in cancer: apoptosis takes center stage. Cancer Res. 2003;63:1-5. PMID: 12517767

30 Otsuka A, Nomura T, Rerknimitr P, Seidel JA, Honda T, Kabashima K. The interplay between genetic and environmental factors in the pathogenesis of atopic dermatitis. Immunol Rev. 2017;278:246-62. DOI: 10.1111/imr.12545, PMID: 28658541

31 Kamide D, Yamashita T, Araki K, Tomifuji M, Shiotani A. Hangeshashinto (TJ-14) prevents radiation-induced mucositis by suppressing cyclooxygenase-2 expression and chemotaxis of inflammatory cells. Clin Transl Oncol. 2017;19:1329-36. DOI: 10.1007/s12094-017-1672-8, PMID: 28516399
32 Ara T, Honjo K, Fujinami Y, Hattori T, Imamura Y, Wang PL. Preventive effects of a kampo medicine, orento on inflammatory responses in lipopolysaccharide treated human gingival fibroblasts. Biol Pharm Bull. 2010;33:611-6. DOI: 10.1248/ bpb.33.611, PMID: 20410594

33 Han C, Guo J. Antibacterial and anti-inflammatory activity of traditional Chinese herb pairs, Angelica sinensis and Sophora flavescens. Inflammation. 2012;35:913-9. DOI: 10.1007/ s10753-011-9393-6, PMID: 21976127

34 Kono T, Kaneko A, Matsumoto C, Miyagi C, Ohbuchi K, Mizuhara Y, et al. Multitargeted effects of hangeshashinto for treatment of chemotherapy-induced oral mucositis on inducible prostaglandin E2 production in human oral keratinocytes. Integr Cancer Ther. 2014;13:435-45. DOI: 10.1177/1534735413520035, PMID: 24501112

35 Chi YS, Kim HP. Suppression of cyclooxygenase-2 expression of skin fibroblasts by wogonin, a plant flavone from Scutellaria radix. Prostaglandins Leukot Essent Fatty Acids. 2005;72:59-66. DOI: 10.1016/j.plefa.2004.04.009, PMID: 15589400

36 Samosorn S, Tanwirat B, Muhamad N, Casadei G, Tomkiewicz D, Lewis K, et al. Antibacterial activity of berberine-NorA pump inhibitor hybrids with a methylene ether linking group. Bioorg Med Chem. 2009;17:3866-72. DOI: 10.1016/j.bmc.2009.04.028, PMID: 19419877

37 Rohrer U, Kunz EM, Lenkeit K, Schaffner W, Meyer J. Antimicrobial activity of Mahonia aquifolium and two of its alkaloids against oral bacteria. Schweiz Monatsschr Zahnmed. 2007;117:1126-31. PMID: 18072463 